http://dx.doi.org/10.18778/7969-144-9.02

MAGDALENA KWIATKOWSKA*

\title{
Rynek - polityka - edukacja. \\ Wydawcy profesjonalni w Królestwie Polskim wobec programów upowszechniania i popularyzacji wiedzy na przełomie XIX i XX wieku
}

Przed blisko stu dwudziestu laty ukazał się w Warszawie Podręcznik księgarski Teodora Paprockiego. Pierwsza polska publikacja tego rodzaju wieńczyła działalność wybitnego księgarza i wydawcy warszawskiego, zmarłego krótko przed ukończeniem druku1. Dzisiejszemu czytelnikowi tytuł opracowania Paprockiego może się wydać mylący. Zawartość publikacji i jej adres czytelniczy wyjaśnia obszerny podtytuł Przewodnik praktyczny dla wydawców, księgarzy, pomocników i praktykantów księgarskich, na podstawie swojskich i obcych źródeł opracowa$n y^{2}$. Całość składa się z sześciu działów i skorowidza rzeczowego. Pracy księgarza w ścisłym tego słowa znaczeniu dotyczą trzy środkowe działy³.

Dla historyka ruchu wydawniczego niewątpliwie najciekawsze są dwa działy: pierwszy, zatytułowany „Księgarnia nakładowa”, oraz piąty - „Prawo prasowe”. Dział pierwszy jest systematycznym wykładem wiedzy na temat działalności księgarni nakładowej, czyli oficyny wydawniczej o charakterze komercyjnym. W ówczesnych warunkach, przy relatywnie małej polskiej ofercie wydawniczej oraz wąskim kręgu nabywców książki, samodzielne firmy wydawnicze nie miały szansy rozwoju i dłuższego utrzymania się na rynku. Działalność wydawniczą prowadzono przeważnie przy dobrze prosperującym handlu księgarskim (rzadziej

* Dr, Uniwersytet Łódzki, Wydział Filologiczny, Katedra Bibliotekoznawstwa i Informacji Naukowej, 90-237 Łódź, ul. Jana Matejki 34A.

1 J. Racięcka, Paprocki Teodor (ok. 1857-6 V 1895), [w:] Słownik pracowników książki polskiej, Warszawa-Łódź 1972, s. 658-659.

2 Podręcznik księgarski [...], red. T. Paprocki, Warszawa 1896.

3 Są to: Dział II: „Księgarnia sortymentowa”, Dział III: „Korespondencja księgarska”, Dział IV: „Rachunkowość i buchalterya” i ponadto Dział VI: „Słownik wyrazów używanych w księgarstwie”. 
- przy drukarni), a podejmowanie inicjatyw edytorskich i finansowanie nakładów dowodziło zarówno ambicji księgarza, jak i zadowalających efektów działu handlowego. Rozwój działu wydawniczego był wynikiem dobrej znajomości rynku i trafnych decyzji przy kształtowaniu repertuaru przez właściciela firmy ${ }^{4}$.

W rozdziale poświęconym doborowi tytułów do druku Paprocki podkreśla, że w odniesieniu do inicjatywy edytorskiej wydawca pełni rolę dwojaką: po pierwsze, inicjuje prace pisarskie i wyszukuje autorów dla takich działów piśmiennictwa, jak poradniki i podręczniki, książki szkolne i książki dla dzieci, słowniki, encyklopedie i przewodniki, większość opracowań popularnych z zakresu nauk przyrodniczych i historycznych; po drugie, nie ingerując w treść, dokonuje wyboru spośród ofert składanych przez samych twórców, co ma miejsce w przypadku literatury pięknej (ściślej - poezji), piśmiennictwa stricte naukowego, monografii ${ }^{5}$. Omawiając szerzej różne strategie współpracy oficyny z autorami i problem wpływu zawodowego wydawcy na ostateczny kształt tekstu, z oczywistych powodów Paprocki nie wspomniał o ograniczeniach natury politycznej. Istnienie cenzury skwitował, przytaczając - bez komentarza - przekłady ustaw cenzuralnych obowiązujących w trzech państwach zaborczych. Swoją wymowę posiadało zestawienie austriackiego i niemieckiego prawa prasowego z restrykcyjną rosyjską ustawą o druku obowiązującą w Królestwie Polskim.

Mając na względzie uwagi poczynione u schyłku XIX wieku przez fachowca, uczestnika i zarazem teoretyka rynku książki, warto przyjrzeć się niektórym aspektom działalności wydawców profesjonalnych Królestwa Polskiego w zakresie upowszechniania wiedzy i kooperacji na tym polu ze światem nauki oraz z twórcami opracowań popularnonaukowych adresowanych do czytelnika wykształconego, lecz niespecjalisty, i do osób kształcących się na poziomie średnim i wyższym.

Należy podkreślić, że w ostatnich trzech dekadach XIX wieku ważną rolę w omawianej sferze rynku książki odgrywali różnego typu wydawcy nieprofesjonalni. Wśród nich można wymienić nieformalne grupy specjalistów promujących europejskie i rodzime piśmiennictwo ze swojej dziedziny wiedzy, redakcje czasopism opiniotwórczych (m.in. „Głosu”, „Prawdy”, „Wędrowca”), wreszcie samych autorów i tłumaczy ${ }^{6}$. Wydawcy nieprofesjonalni z reguły odwoływali się do własnego programu edukacji społeczeństwa polskiego, zarówno w węższym, oświatowym rozumieniu tego pojęcia, przez dostarczenie opracowań prezentujących wiedzę klasyczną, jak i w rozumieniu szerokim, odnoszącym się do przekonań szerszych kręgów inteligencji, przez działania zmierzające do upowszechnienia najnowszych osiągnięć. Od lat osiemdziesiątych XIX wieku przygotowywane w tych środowiskach edycje piśmiennictwa naukowego i podręczników akademickich otrzymywały w Kongresówce wsparcie finansowe instytucji mecenatu

${ }^{4}$ M. Mlekicka, Wydawcy książek w Warszawie w okresie zaborów, Warszawa 1987, s. 29-31.

${ }^{5}$ Podręcznik księgarski..., s. 10.

${ }^{6}$ M. Mlekicka, Wydawcy książek w Warszawie..., s. 32; M. Kwiatkowska, Autorzy jako wydawcy książki naukowej w Warszawie w latach 1860-1914, „Roczniki Biblioteczne” 2002, R. XLVI, s. 287322; taż, Udział redakcji warszawskich czasopism kulturalno-społecznych w rozpowszechnianiu książki naukowej w drugiej połowie XIX i na początku XX wieku, „Acta Universitatis Lodziensis” 2005, Folia Librorum 12, s. 20-32. 
społecznego, tj. założonej w 1881 roku Kasy Pomocy Osobom Pracującym na Polu Naukowym im. Józefa Mianowskiego ${ }^{7}$. W przeciwieństwie do przedsięwzięć księgarń nakładowych, działania wydawców nieprofesjonalnych raczej nie były obliczone na zysk.

Początki poważniejszego zaangażowania się wydawców komercyjnych Królestwa Polskiego w publikowanie książek popularyzujących naukę na poziomie średnim i wyższym przypadają na przełom lat sześćdziesiątych i siedemdziesiątych XIX wieku. Był to efekt oddziaływania koncepcji pozytywistycznych propagowanych na łamach czasopism warszawskich („Niwy”, „Opiekuna Domowego”, „Przeglądu Tygodniowego”). Zaproponowany przez redakcje „młodej” prasy program udostępnienia podstawowych tekstów pozytywizmu szybko podchwyciły profesjonalne oficyny wydawnicze, wykorzystując zainteresowanie czytelników książką naukową ${ }^{8}$ Redakcja pozytywistycznej „Niwy” wyraziła nawet „zadowolenie z tego, że panowie księgarze zabierają się do nakładów na dzieła naukowe większych rozmiarów i że źle na tym nie wychodzą"9.

W roku 1873, na który przypadło apogeum pierwszej na większą skalę prowadzonej w Królestwie Polskim akcji popularyzatorskiej, Maurycy Orgelbrand kończył dwutomową edycję Dziejów rozwoju umysłowego Europy Johna W. Drapera (1872-1873). Wtedy też firma Gebethnera i Wolffa, zdobywająca sobie właśnie dominującą pozycję na polskim rynku książki, wydała Historię cywilizacji Anglii Henry'ego T. Buckle'a, jedną z podstawowych lektur epoki.

W tym samym roku Adam Wiślicki, redaktor „Przeglądu Tygodniowego” i właściciel dochodowej drukarni, wypuścił „Bibliotekę 50-tomową za 5 Rubli”. Ciesząca się dużym rozgłosem tania seria wydawnicza miała rozszerzyć krąg adresatów realizowanego od kilku lat przez Wiślickiego programu upowszechniania zdobyczy nauki i nowych prądów umysłowych. W jej skład, oprócz opracowań naukowych, weszły popularne odczyty, poradniki i „pogadanki”. Niską cenę książek, wydawanych również poza „Biblioteką 50-tomową”, uzyskiwał jednak Wiślicki m.in. kosztem pospiesznie wykonanych, niestarannych przekładów ${ }^{10}$.

W połowie 1873 roku na rynku książki doszło do zawiązania się Spółki Wydawniczej Księgarzy. Tworzyli ją właściciele pięciu największych oficyn warszawskich: Gustaw Gebethner i Robert Wolff, Michał Glücksberg, Maurycy Orgelbrand, Gustaw K. Sennewald oraz Edward Wende ${ }^{11}$. Charakterystyczne, że Spółka zorganizowana w celu zwalczenia konkurencji między udziałowcami rozpoczęła działalność nie od beletrystyki, która oprócz podręczników szkolnych i druków muzycznych stanowiła obszar najsilniejszej rywalizacji na rynku książki, lecz od publikacji naukowych dla inteligencji. Nie można zatem wykluczyć, że istotnym czynnikiem mobilizującym do powołania swego rodzaju „nadwydawnictwa” był wzrost zainteresowania książką naukową.

\footnotetext{
7 Podręcznik księgarski..., s. 10.

8 L. Zasztowt, Popularyzacja nauki w Królestwie Polskim 1864-1905, Wrocław 1989, s. 142-146.

9 „Niwa” 1873, nr 27, s. 68.

10 L. Zasztowt, Popularyzacja nauki..., s. 126-127.

11 Spółka Wydawnicza Księgarzy istniała do roku 1888. M. Mlekicka, Wydawcy książek w Warszawie..., s. 252-253.
} 
Wspólnicy wydali m.in. dwie różniące się charakterem serie publikacji, raz jeszcze obejmujące przekłady piśmiennictwa zachodniego i rosyjskiego. Pierwsza, adresowana do szerszych kręgów czytelników, zawierała - jak głosił jej tytuł - „Dwanaście Odczytów Popularnych”. Ogłoszono ją w formie dwu-, trzyarkuszowych broszurek, kopiując do pewnego stopnia dawniejsze wydawnictwo niemieckie $^{12}$. Serię drugą, „Biblioteka Naukowa Międzynarodowa”, wzorowano na pionierskim wydawnictwie pomysłu kilku firm zachodnich, które wspólnie planowały ogłosić ok. czterdziestu książek popularnonaukowych ${ }^{13}$. Nowe opracowania uczonych z obu stron Atlantyku miały prezentować osiągnięcia różnych dyscyplin nauki z perspektywy teorii Darwinowskiej. Seria była pomyślana inaczej niż „Biblioteka 50-tomowa” Wiślickiego. Obejmowała teksty nowo powstające i wyrównane, jeśli chodzi o poziom opracowania ${ }^{14}$. Tłumaczenie dzieł powierzono specjalistom, m.in. Franciszkowi Krupińskiemu, autorowi pierwszego na gruncie warszawskim opracowania na temat pozytywizmu oraz profesorom Uniwersytetu Warszawskiego, medycyny - Feliksowi Nawrockiemu i przyrodnikowi - Augustowi Wrześniowskiemu.

Realizacja polskiej wersji „Biblioteki Naukowej Międzynarodowej”, okrojonej już w założeniu, urwała się po ogłoszeniu zaledwie sześciu przekładów - z powodu małego zainteresowania czytelników, a zatem niewielkich wpływów z prenumeraty, zwyczajowo rozpisanej na tak obszerne przedsięwzięcie. Ksiądz Krupiński w recenzji „Biblioteki” zwrócił uwagę na nieodpowiadający potrzebom rynku wybór tekstów do tłumaczenia, ograniczony prawie wyłącznie do prac z zakresu nauk przyrodniczych, i podpowiadał, by wydawać książki twórców reprezentujących nauki humanistyczne i społeczne, np. prace Herberta Spencera ${ }^{15}$. Urzeczywistnienie postulatów recenzenta „Biblioteki Naukowej Międzynarodowej” nie było oczywiste. Po pierwsze, książek niektórych autorów, m.in. Spencera właśnie, cenzura warszawska nie dopuszczała do druku w wydawnictwie ciągłym objętym prenumeratą ${ }^{16}$. Po drugie, jeśli nawet cenzura nie zgłaszała zastrzeżeń, edycje książek, które już wcześniej zdobyły rozgłos, oficyny finansowały samodzielnie, bez asekuracji kapitału Spółki17.

Nowy kierunek w działalności wydawniczej firm nakładowych podlegał, co oczywiste, procesom charakterystycznym dla całego ruchu wydawniczego w Królestwie Polskim. Chociaż pojawił się równocześnie z podobnymi inicjatywa-

12 Wstęp od redakcji, [w:] H. Helmholtz, O stosunku nauk przyrodzonych do ogółu wiedzy, Warszawa 1874, s. 1 nlb. Już w 1868 r. do tegoż niemieckiego pierwowzoru odwołał się Adam Wiślicki, wydając serię „Wiedza. Zbiór Popularnych Odczytów z Literatury i Nauk”.

13 Pierwotnie „Bibliotekę Naukową Międzynarodową” planowała wydać pierwsza redakcja „Niwy”. Plan rozbił się o „przeszkody pieniężne”. „Niwa” 1878, t. XIII, z. 83, s. 819.

14 H. Spencer, Przedmowa, [w:] tenże, Wstęp do socjologii, Warszawa 1884, s. I-II; „Niwa” 1874, nr 56, s. 191.

15 Recenzja sześciu przekładów, które ukazały się w serii Spółki Wydawniczej Księgarzy pióra F. K. [Franciszka Krupińskiego], „Ateneum” 1876, t. 1, z. 3, s. 685.

16 M. Brykalska, Aleksander Świętochowski. Biografia, t. 1, Warszawa 1987, s. 136.

17 Np. proponowany przez Krupińskiego Wstęp do socjologii Spencera ukazał się nakładem Gebethnera i Wolffa (1884), cieszące się dużym zainteresowaniem J. W. Drapera Dzieje stosunku wiary do rozumu dwukrotnie w ciągu krótkiego czasu wydała mała księgarnia Ludwika Polaka (1882 i 1884). 
mi wydawców nieprofesjonalnych i korzystał z ich doświadczeń, posiadał jednak swoiste oblicze i własną dynamikę. Pewna jego odrębność była rezultatem poszukiwania takiego modelu realizacji programu popularyzacji nauki, który pozwoliłby wydawcom uczestniczyć w tworzeniu wartości kultury wysokiej i zarazem czynił przedsięwzięcia rentownymi.

Dla oficyn zabiegających o czytelnika wykształconego dogodniejsza okazała się metoda publikowania prac naukowych w seriach o mieszanym programie literacko-naukowym. Tę formę rozpowszechniania zapoczątkował w Królestwie Polskim Salomon Lewental w ramach „Biblioteki Najcelniejszych Utworów Literatury Europejskiej” ukazującej się od 1874 roku przez ok. ćwierć wieku¹8. Powodzenie Lewentalowskiej „Biblioteki” należy przypisać kilku czynnikom. Po pierwsze, wydawca przyjął charakterystyczną dla stosunkowo niewielkich rynków (powszechnie stosowaną przez redakcje warszawskich tygodników opiniotwórczych) oszczędną formę edytorską, wypuszczając książki w postaci zeszytów (właściwie - poszytów) powiązanych z cieszącym się sporym zainteresowaniem publiczności ilustrowanym pismem „Kłosy” i tygodnikiem „Romans i Powieść”. Po drugie, repertuar „Biblioteki Najcelniejszych Utworów Literatury Europejskiej” odznaczał się starannym doborem, uwzględniającym również piśmiennictwo polskie ${ }^{19}$. Była to zasługa redaktorów serii, Fryderyka H. Lewestama, przede wszystkim zaś jego następcy, Piotra Chmielowskiego, który pełnił tę funkcję w latach 1878-1897. Chmielowski w ciągu ponad dwudziestu lat współpracy z wydawnictwem Lewentala przygotował do druku szereg utworów literatury polskiej od XVI do XIX wieku oraz większość dzieł naukowych wydanych w „Bibliotece Najcelniejszych Utworów”, ponadto brał udział w pracach przekładowych ${ }^{20}$.

O skali trudności, na jakie natrafiali wydawcy działający w myśl reguł rynkowych - stale konfrontowanych z zarządzeniami cenzury - świadczy stosunkowo niewielka liczba książek naukowych ogłoszonych w ramach programów inicjowanych przez oficyny komercyjne. Wprawdzie w ostatnim dwudziestopięcioleciu XIX wieku dostrzec można nieprzerwany ciąg kolejno podejmowanych prób, należy jednak podkreślić, że od schyłku lat siedemdziesiątych nawet duże oficyny w Warszawie nie zdobyły się na przygotowanie większego zbioru tekstów w formie wydawnictwa seryjnego, który - po rozpisaniu prenumeraty - miałby szanse trafić do szerszej publiczności inteligenckiej oraz do młodzieży gimnazjalnej i studenckiej.

Nie oznacza to, że wydawcy komercyjni odwrócili się w swoich wyborach od książki naukowej. Ich uczestnictwo w tym segmencie produkcji wydawniczej zmieniało się wraz z rozwojem rynku i sukcesywnie postępującą specjalizacją oferty. Pewien wpływ na zmiany obserwowane pod koniec XIX wieku miał też proces

18 Druk ostatnich tomów „Biblioteki Najcelniejszych Utworów Literatury Europejskiej” kończono po $1900 \mathrm{r}$.

19 K. Estreicher, Bibliografia polska XIX stulecia, cz. 1, wyd. 2, t. II, Kraków 1977, s. 298-301.

20 W latach 90. XIX w., kiedy opiekę nad wydawnictwem sprawował Chmielowski za pośrednictwem listów z Zakopanego, do współpracy, jako redaktora kilku tomów i tłumacza, wciągnął Antoniego Sygietyńskiego. Zob. Korespondencja Antoniego Sygietyńskiego i Piotra Chmielowskiego. Dwugłos z lat 1880-1904, oprac. E. Kiernicki, Wrocław-Warszawa-Kraków 1963, s. 56 i in. 
wyodrębnienia się i ukształtowania wąsko specjalistycznego pisarstwa stricte naukowego. Na to pole wydawcy komercyjni wstępowali wyjątkowo, skłaniając się raczej ku finansowaniu nakładów opracowań dostępnych dla szerszych kręgów inteligencji.

Od ok. 1880 roku wydawanie polskiego piśmiennictwa z zakresu dyscyplin humanistycznych stało się domeną rozbudowującej się intensywnie firmy Gebethner i Wolff, działającej już wówczas również w Krakowie pod nazwą Gebethner i Spółka. Obie placówki wiodły prym w publikowaniu opracowań z zakresu historiografii i literaturoznawstwa przygotowanych przez badaczy z trzech zaborów ${ }^{21}$. W znacznie mniej licznych edycjach piśmiennictwa zagranicznego oficyna Gebethnerowska zaznaczyła się jako instytucja wspomagająca wychowawców i pedagogów. Między innymi w latach 1879-1907 sześciokrotnie wydano tam głośny zbiór studiów Herberta Spencera O wychowaniu umysłowym, moralnym i fizycznym w przekładzie Michała Siemiradzkiego, dwukrotnie (1890; 1899) pierwszy tom podręcznika Bernarda Pereza Psychologia dziecka, w przekładzie Marii Dzierzanowskiej (1890), a także Naukę wychowania Aleksandra Baina, uzupełnioną o metodykę nauczania języka polskiego przez tłumacza, księdza Franciszka Krupińskiego $(1880)^{22}$.

Zagadnienia pedagogiki, wychowania i psychologii pozostawały też w kręgu zainteresowań Teodora Paprockiego. Autor Podręcznika księgarskiego skupił wokół swojej oficyny wybitnych przedstawicieli wymienionych dyscyplin i praktyków (Jana Władysława Dawida, Adolfa Dygasińskiego, Justynę Strzemeską, Marię Weryho-Radziwiłłowiczową), którzy publikowali u niego prace własne, a także współpracowali jako tłumacze i redaktorzy. Dział naukowy księgarni nakładowej Paprockiego w latach osiemdziesiątych i dziewięćdziesiątych pracował nie mniej intensywnie niż w firmie Gebethnera i Wolffa. Repertuar oficyny był jednak bardziej zróżnicowany - zarówno z punktu widzenia treści oferowanych dzieł, jak i typu publikacji. Oprócz książek pedagogicznych i psychologicznych z wymienionych dziedzin Paprocki wydawał opracowania z zakresu filozofii i estetyki, logiki i historii kultury, antropologii i literaturoznawstwa, nauk geograficznych i przyrodniczych. W ostatnich dziedzinach zaznaczyli swą obecność nauczyciele warszawscy i pracownicy nauki zarazem, Jan Józef Boguski i Wacław Nałkowski. W edycjach piśmiennictwa polskiego i obcego dostrzec można nie tylko opracowania syntetyzujące najnowsze osiągnięcia, ale też podręczniki akademickie, a nawet specjalistyczne studia i publikacje źródłowe.

Niezależnie od różnic w repertuarze naukowym, naukowo-dydaktycznym czy popularnonaukowym adresowanym do publiczności wykształconej, oficyny Gebethnerowska i Paprockiego odegrały ważną rolę w dziele wspierania polskiego piśmiennictwa w okresie szerszego zainteresowania wykształceniem wyższym i rozwijającego się ruchu samokształceniowego. Ich publikacje wspierały trwające

21 J. Muszkowski, Z dziejów firmy Gebethner i Wolff, Warszawa 1938, s. 34, tabl. II doklejona na końcu książki.

22 Dział książek szkolnych, pielęgnowany w firmie Gebethner i Wolff niemal od początku jej istnienia, rozwinął się na większą skalę na początku XX w., wraz z powstaniem polskiego szkolnictwa w Kongresówce. 
niemal ćwierć wieku wykłady tajnego Uniwersytetu Latającego oraz nielegalne kółka młodzieży gimnazjalnej i prowadzone przez nie tajne biblioteki książek akceptowanych przez cenzurę warszawską ${ }^{23}$.

Przełom XIX i XX stulecia zaznaczył się wyraźnymi zmianami w sposobie uczestniczenia komercyjnych firm wydawniczych w dziele upowszechniania i popularyzacji nauki. Zmiany te towarzyszyły przeobrażeniom makrospołecznym i wydarzeniom politycznym w Królestwie Polskim na początku XX wieku. W swoisty sposób znalazły też w nich odzwierciedlenie - zaproponowane przez środowiska nauczycielskie, ludzi nauki i społeczników - programy edukacyjne wspierające ruch samokształceniowy. Asumpt do działań w tym kierunku dała akcja wspierania samokształcenia prowadzona przez „Przegląd Pedagogiczny”24 oraz "Głos” w okresie, gdy pismem kierował Jan Władysław Dawid ${ }^{25}$, przede wszystkim zaś powodzenie, jakim cieszył się wydawany od 1898 roku „Poradnik dla samouków”. Z tych środowisk wyszły swego rodzaju wzory publikacji wspomagających samokształcenie. Były to: Wykłady naukowe ukazujące się od 1895 roku na łamach „Przeglądu Pedagogicznego" oraz tania biblioteczka popularnonaukowa wydawana w latach 1897-1901 przy „Poradniku dla samouków” pod redakcją Ludwika Krzywickiego ${ }^{26}$. W 1902 roku to ostatnie przedsięwzięcie otrzymało formę zinstytucjonalizowaną w postaci Księgarni Naukowej, którą wraz ze wspólnikami prowadził Aleksander Heflich, główny obok Stanisława Michalskiego wydawca pierwszych tomów „Poradnika dla samouków”.

Repertuar wydawniczy Księgarni Naukowej - która przez ok. dziesięć lat próbowała pracować według wzorów firm komercyjnych - tworzyły książki popularnonaukowe i naukowe z zakresu historii kultury, literaturoznawstwa, nauk matematyczno-przyrodniczych, społecznych i psychologii (nie zabrakło też publicystyki kulturalnej i literatury pięknej)27. Znaczna część książek spełniała kryteria pomocy dla osób zdobywających wykształcenie i przygotowujących się do pracy naukowej, jakie Stanisław Michalski przyjął w „Poradniku dla samouków” oraz podnosił w dyskusji wokół koncepcji popularyzacji nauki i form samokształcenia toczącej się w latach 1903-1904 na łamach „Ogniwa”28.

Podejmowanie działalności wydawniczej na zasadach rynkowych przez osoby aktywne wcześniej w profesjach inteligenckich stanowi swego rodzaju znak

${ }^{23}$ L. Krzywicki, Wspomnienia, t. 2, Warszawa 1958, s. 363-365; D. Tomaszewska, Drogi wyboru. Konspiracyjny ruch samokształceniowy na ziemiach polskich w końcu XIX i na pocz. XX w., Łódź 1987.

24 T. Kamiński, „Przegląd Pedagogiczny” (1882-1905). Zarys monograficzny, Wrocław 1978, s. $60-62$.

25 W. Bułat, „Głos” Jana Władysława Dawida 1900-1905, „Rocznik Historii Czasopiśmiennictwa Polskiego" 1966, z. 2, s. 72.

${ }_{26}$ Por. J. Piskurewicz, W służbie nauki i oświaty. Stanisław Michalski (1865-1949), Warszawa 1993, s. 48-49.

27 I. Lepalczyk, I. Treichel, Heflich Aleksander, [w:] Słownik pracowników książki polskiej..., s. 322; S. Arct, E. Pawłowska, Wydawcy warszawscy w latach 1878-1914. Szkic do dziejów wydawnictw książek w Polsce, [w:] Z dziejów książki i bibliotek w Warszawie, red. S. Tazbir, Warszawa 1961, Zestawienie 4 na końcu książki.

28 J. Piskurewicz, W służbie nauki i oświaty..., s. 56-59; L. Zasztowt, Popularyzacja nauki..., s. 62-68; T. Kamiński, „Przegląd Pedagogiczny”..., s. 190-194; Z. Kmiecik, Prasa warszawska w latach 1886-1904, Wrocław 1989, s. 82-83, 88-89. 
czasu tamtej epoki. Tworzone przez nie oficyny zazwyczaj nie wytrzymywały konkurencji z firmami prowadzonymi przez zawodowych księgarzy-wydawców. A samych twórców, właścicieli i współwłaścicieli tego typu „inteligenckich” wydawnictw z reguły pochłaniały sprawy życia bieżącego, zamykając im nierzadko możliwość legalnej pracy, a nawet przebywania w Królestwie Polskim.

Do tradycyjnych firm komercyjnych, które najwcześniej (ok. 1900 r.) wpisały w swoje plany wydawnicze piśmiennictwo zalecane przez twórców programów wspomagających samokształcenie, a w bieżącej działalności odwoływały się do wskazówek lub opracowań autorów współtworzących programy edukacyjne, należały: wielozadaniowa oficyna Michała Arcta i księgarnia nakładowa działająca pod firmą T. Paprocki i Spółka. Ostatnia z wymienionych placówek w ciągu krótkiego czasu po śmierci Paprockiego (1895) przeszła liczne zmiany własnościowe, a te przyniosły przeobrażenia w organizacji prac wydawniczych, w repertuarze, w kontaktach ze środowiskiem pisarskim. Rozwiązania przyjmowane przez kolejnych właścicieli wnosiły zazwyczaj nową wartość do kultury polskiej i w znaczący sposób zmieniały obraz polskiego ruchu wydawniczego, zwłaszcza w jego części niebeletrystycznej. Saturnin Józef Sikorski i Franciszek Juliusz Granowski, kupując w roku 1896 księgarnię Paprockiego, byli tuż po wydaniu pierwszego poszytu Wielkiego Atlasu Geograficznego (ukończonego w 1905) i w przeddzień rezygnacji z wydawania Wielkiej Encyklopedii Powszechnej Ilustrowanej (1890-1914) - jednego z najpoważniejszych (niestety nieukończonych) polskich przedsięwzięć edytorskich przed I wojną światową. W 1897 roku Encyklopedia stała się półprywatnym „wydawnictwem redakcyjnym”, kierowanym przez Ludwika Krzywickiego bez zaplecza instytucjonalnego. W kolejnym, 1897 roku, z inicjatywy Granowskiego wspólnicy uruchomili inne ważne przedsięwzięcie - „Bibliotekę Dzieł Wyborowych", wydawnictwo seryjne, formalnie niezwiązane z Księgarnią T. Paprocki i Sp.

„Biblioteka Dzieł Wyborowych”, seria-instytucja obejmująca tomiki publikowane co tydzień w prenumeracie przez kolejnych właścicieli, przetrwała niemal trzydzieści lat. Była wydawnictwem o mieszanym programie literacko-popularnonaukowym. Mając niemałe osiągnięcia w upowszechnianiu czytelnictwa, zasługuje na opracowanie monograficzne. Warto może tylko zauważyć, że skład pierwszej redakcji tworzyli m.in. Piotr Chmielowski i Julian Ochorowicz, którzy zadbali o właściwą reprezentację tytułów w części naukowej ${ }^{29}$. Jak wynika z korespondencji, w nowym wydawnictwie Chmielowski wprost nie nawiązywał do programów edukacyjnych „Przeglądu Pedagogicznego” i „Poradnika dla samouków”, raczej zamierzał kontynuować politykę doboru książek stosowaną w odchodzącej właśnie do przeszłości Lewentalowskiej „Bibliotece Najcelniejszych Utworów Literatury Europejskiej"30. Zaproponował kilka własnych opracowań, przeważnie drukowanych wcześniej na łamach czasopism naukowych, m.in. Historię literatury polskiej, jedną z ostatnich swych książek ${ }^{31}$. Plany były rozleglejsze, tu jednak

29 J. Dunin, Rozwój cech wydawniczych polskiej książki literackiej XIX-XX wieku, Łódź 1982, s. $171,173$.

30 Korespondencja Antoniego Sygietyńskiego..., s. 77 (list z 12 III 1899).

${ }^{31} \mathrm{~W}$ przedmowie do Historii literatury polskiej (t. 1, s. 18) Bronisław Chlebowski pisał: „[...] opracował Chmielowski dla Biblioteki Dzieł Wyborowych szerszych rozmiarów zarys, mający na celu 
dała o sobie znać cenzura warszawska, tradycyjnie - mimo złagodzenia kursu - niedopuszczająca do szerszego rozpowszechnienia treści dostępnych w publikacjach adresowanych do wąskiego kręgu specjalistów ${ }^{32}$.

Do programu samokształceniowego wydawcy „Poradnika dla samouków” nawiązał Stanisław Kucharski, ostatni właściciel księgarni T. Paprocki i Spółka. Kucharski - postać tyleż barwna co kontrowersyjna, do niedawna duchowny, wkrótce aktywista SDKPiL ${ }^{33}$ - wzorował się na rozwiązaniach stosowanych już od kilku dziesięcioleci przez redakcje czasopism społeczno-kulturalnych: książki wydawał równolegle i w ścisłym związku z czasopismem, a właściwie z trzema kolejnymi dwutygodnikami. Początkowo osią przedsięwzięcia był dwutygodnik „Poradnik dla Czytających Książki. Dwutygodnik Sprawozdawczo-Literacki” - pismo założone jeszcze przez poprzednich właścicieli księgarni Paprockiego w celu rozpropagowania wydawnictw własnych. Za namową Wacława Nałkowskiego w 1901 roku redakcję periodyku i powiązanych z nim publikacji książkowych objął Ludwik Krzywicki3i.

Krzywicki, zapewniając sobie współpracę wybitnych uczonych i aktywnych uczestników ruchu samokształceniowego, zmierzał do przekształcenia „Poradnika dla Czytających Książki” w systematyczny przewodnik dla ogółu czytelników i dla samouków. W kolejnych zeszytach prezentowano bieżące piśmiennictwo z różnych dziedzin nauki lub poszczególne typy publikacji, zamieszczano recenzje i szersze omówienia zawierające opinie na temat przydatności książek dostępnych na rynku w toku samokształcenia, a także artykuły popularnonaukowe. Jednocześnie pod kierunkiem Krzywickiego przygotowywano do druku ok. dwudziestu książek, których treść korespondowała z planem drugiej serii „Poradnika dla samouków" (zrealizowanym w tomach Świat i człowiek i Dzieje myśli) ${ }^{35}$. W zespole tym znalazły się książki omawiające „rozwój świata” i „rozwój nauki o świecie” - jak w odniesieniu do „Poradnika dla samouków” ujął to Stanisław Michalski ${ }^{36}$. O ile w przypadku wydawnictwa Michalskiego mamy do czynienia z nowymi tekstami, pisanymi specjalnie na jego potrzeby przez czołówkę przedstawicieli nauki polskiej, o tyle w projekcie Krzywickiego dominowały przekłady z literatury obcej. Należy podkreślić, że wybór książek i poziom przekładów otrzymały dobre i bardzo dobre oceny krytyki. Pisano, że stoją one „na wysokości nauki współczesnej” i są „cenne w swoim rodzaju”37.

przedstawienie ogółowi całej sumy najważniejszych rezultatów dotychczasowej pracy nad dziejami literatury [...]". Zob. też: Korespondencja Antoniego Sygietyńskiego..., s. 99-118; A. Brückner, Piotr Chmielowski, „Kwartalnik Historyczny” 1904, t. 18, s. 403-409 (przedruk w: A. Brückner, Kultura, piśmiennictwo, folklor. Wybór prac, red. W. Berbelicki, T. Ulewicz, Warszawa 1974, s. 485-492).

${ }^{32}$ Myślano o wydaniu studium o wileńskich Masonach i szubrawcach Chmielowskiego oraz Pamiętników Józefa Wybickiego, a także jednej z prac Juliana Bartoszewicza. Zob. Korespondencja Antoniego Sygietyńskiego..., s. 55, 58-59, 118.

33 M. Adrianek, Kucharski Stanisław, [w:] Słownik pracowników książki polskiej..., s. 481-482.

34 L. Krzywicki, Wspomnienia, t. 3, Warszawa 1959, s. 198.

35 H. Radlińska i I. Lepalczyk (Stanisława Michalskiego autobiografia i działalność oświatowa, Wrocław 1967, s. 61) pisały, że program „Poradnika dla Czytających Książki” był ,jak gdyby rozszerzeniem «Poradnika dla samouków»".

36 J. Piskurewicz, $W$ służbie nauki i oświaty..., s. 52.

37 „Książka” 1902, nr 12, s. 413; 1904, nr 7, s. 274-275; „Ogniwo” 1903, nr 40, s. 947-948. 
Pod firmą „Poradnika dla Czytających Książki” wydano zaledwie kilka z planowanych dzieł. Niezwykle pożyteczne dla ruchu samokształceniowego działania polegające na włączeniu się oficyny komercyjnej w realizację projektu środowisk naukowych i pedagogicznych nie wytrzymały próby czasu. W wyniku ograniczania przez właściciela firmy samodzielności redakcji „cały nasz zespół - pisał Krzywicki - opuścił Kucharskiego”38. Edycję dwutygodnika „Poradnik dla Czytających Książki” zakończono już w połowie 1902 roku. Kilka książek przygotowanych do druku ogłosili członkowie odchodzącej redakcji sumptem prywatnym, oddając publikacje na skład główny do Księgarni Naukowej39.

Co się zaś tyczy pozostałych tytułów przewidzianych do odrębnej publikacji, to przynajmniej część pierwotnego planu (być może rozszerzonego o własne propozycje) zrealizował Kucharski w latach 1902-1904 w ramach „Biblioteki Samokształcenia" - serii wydawniczej utworzonej specjalnie w tym celu ${ }^{40}$. Kolejne przedsięwzięcia firmy, tj. dwa czasopisma: „Biblioteka Samokształcenia” (ukazująca się w ostatnim kwartale 1903 r.) i „Biblioteka Naukowa” (1904-1909), oraz seria o tej samej nazwie, kontynuowały poprzedni program tylko w pewnym zakresie. Na dobór książek w coraz większym stopniu wpływały radykalne przekonania polityczne ostatniego właściciela księgarni działającej pod firmą T. Paprocki i Spółka ${ }^{41}$. Choć ciągle publikowano teksty naukowe i popularnonaukowe, periodyki zatraciły charakter metodycznego przewodnika i biblioteczki dla samouków ${ }^{42}$. Zmieniła się też forma edytorska dwutygodnika. „Biblioteka Naukowa" przekształciła się w wydawnictwo hybrydowe: pojedynczy zeszyt zawierał w sobie zszyte składki kilku publikowanych książek firmowanych nazwiskiem wydawcy.

Odmienną drogę uczestnictwa w ruchu samokształceniowym obrała oficyna Michała Arcta (notabene Kucharski widział w niej główną współzawodniczkę w dziale publikacji upowszechniających wiedzę). Ta druga po księgarni Gebethnera i Wolffa firma wydawnicza w Królestwie od kilku dziesięcioleci budowała swą pozycję na rynku książki przede wszystkim jako wydawca podręczników szkolnych, książek dla dzieci i młodzieży oraz słowników opracowywanych przez Michała Arcta lub przy jego udziale. Nakłady książek popularnonaukowych dla odbiorcy wykształconego podejmowano tam rzadziej. Oprócz niezrealizowanych zobowiązań Artura Gruszeckiego, poprzedniego właściciela warszawskiej księgarni Arctów, finansowano niektóre publikacje redakcji „Przeglądu Pedagogicznego” oraz książki stałych współpracowników tego pisma, którzy pełnili w wydawnictwie

${ }^{38}$ L. Krzywicki, Wspomnienia..., s. 200.

39 H. Radlińska, I. Lepalczyk, Stanisława Michalskiego autobiografia..., s. 61.

40 Por. prospekt pt. Biblioteka Samokształcenia. Wydawnictwo naukowe, [w:] Katalog dzieł nakładowych Księgarni T. Paprockiego i Spółki, Warszawa 1902.

41 W latach 1905-1908 w serii „Biblioteka Naukowa”, oprócz prac religioznawczych Ignacego Radlińskiego oraz Życia Jezusa Ernesta Renana, ukazały się książki F. Engelsa, K. Kautsky’ego, F. Lassalle'a, K. Marksa.

42 Por. polemikę Redakcji miesięcznika „Książka” z Kucharskim („Książka” 1906, nr 1, s. 3) oraz anonimową recenzję dwutygodnika „Biblioteka Samokształcenia”, prawdopodobnie pióra Adama Marburga („Książka” 1904, nr 7, s. 274-275). 
funkcję konsultantów ${ }^{43}$. Zdarzały się również nakłady książek z zakresu nauk pedagogicznych oraz podręczniki akademickie ${ }^{44}$.

Od schyłku XIX wieku Michał Arct inicjował kolejne serie wydawnicze o charakterze popularnonaukowym i niejednakowym adresie czytelniczym. Najwcześniejsza z nich, założona w 1901 roku pn. „Książki dla Wszystkich” prezentowała szeroki zakres treści i stopień trudności poszczególnych opracowań. Najciekawszą grupę publikacji popularnonaukowych wydanych w serii „Książki dla Wszystkich" stanowią prace przygotowane na zamówienie i według wskazówek Arcta. Były to szkice na temat dorobku wybitnych pisarzy i uczonych lub studia poświęcone niektórym aspektom ich twórczości. Autorami tekstów byli m.in.: Stanisław Brzozowski, Bronisław Chlebowski, Henryk Galle (stały współpracownik i doradca firmy Arcta) $)^{45}$. Teksty te były w rzeczywistości albo pierwszymi próbami opracowania pewnych zagadnień, albo też gruntowną syntezą opartą na literaturze przedmiotu i badaniach własnych.

Wobec zespołu publikacji serii „Książki dla Wszystkich” krytyka wysuwała zarzut zbyt wysokiego stopnia trudności6 ${ }^{4}$. O książkach Brzozowskiego i Władysława Mieczysława Kozłowskiego pisał Piotr Chmielowski: „Są to utwory krytyczne w całym znaczeniu tego wyrazu, analizy szczegółowe, dla umysłów wyćwiczonych dostępne i dla nich też kreślone” i dodawał: „ich autorowie mieli na widoku tzw. inteligencję wyższą". Chmielowski diagnozował ponadto, że do serii masowej trafiły przypadkowo z powodu niedostatku "nakładców na studia literackie"47.

Pominąwszy motywacje leżące u podstaw decyzji o wydaniu prac naukowych w ramach popularnej serii „Książki dla Wszystkich”, warto zauważyć, że niejednolity poziom opracowań, występowanie obok siebie pozycji o elementarnym i najwyższym stopniu trudności, różnorodność typów publikacji - wszystko to mogło budzić kontrowersje w czasie, gdy krąg odbiorców opracowań naukowych i popularnonaukowych znacznie poszerzył się i zróżnicował w stosunku do epoki popowstaniowej. Towarzyszące temu procesowi narastanie zjawiska określonego przez Henryka Hollendra „różnicowaniem się publiczności i dyferencjacją potrzeb"48 rodziło konieczność tworzenia programów wydawniczych o wyraźniej

43 S. Arct, Arctowie. Kartka z dziejów rodziny księgarskiej (3), „Księgarz” 1958, nr 6, s. 133.

44 W latach 1908-1911 Michał Arct, wspólnie z Iwowską oficyną Alfreda Altenberga, sfinansował edycję wykładów Historii literatury polskiej Romana Pilata, a w 1913 r. jego nakładem ukazał się podręcznik przygotowany w krakowskiej Bibliotece Towarzystwa Uniwersytetu Ludowego im. A. Mickiewicza pod redakcją Heleny Radlińskiej Praca oświatowa, jej zadania, metoda, organizacja. Por. S. Arct, Okruchy wspomnień..., s. 172; S. Arct, E. Pawłowska, Wydawcy warszawscy..., s. 342; J. Kacprzyk, Arct Michał, [w:] Słownik pracowników książki polskiej..., s. 15.

45 Chlebowski ogłosił książkę Mikołaj Rej jako pisarz (1905); Galle - charakterystyki pisarzy: Aleksander Świętochowski (1901), Maria Konopnicka (1902), Adam Asnyk (1903); Brzozowski m.in. Józef Kremer jako pisarz, filozof i estetyk (1902), Józefa Kremera poglądy na sztukę i jej historię (1903), Stanisław Wyspiański jako poeta (1903), Jan Śniadecki. Życie i dzieła (1904), Hipolit Taine jako estetyk i krytyk (1902).

46 Por. Zasztowt, Popularyzacja nauki..., s. 114.

47 P. Chmielowski, Popularyzowanie historii literatury polskiej, „Książka” 1904, nr 1, s. 4-5.

48 H. Hollender, Produkcja wydawnicza Królestwa Polskiego na początku XX wieku, [w:] Instytucje - publiczność - sytuacje lektury. Studia z historii czytelnictwa, red. J. Kostecki, t. 3, Warszawa 1991, s. 206. 
określonym celu i adresie czytelniczym publikacji. Wydaje się, że cezurę chronologiczną rozwoju programów edukacyjnych w firmach komercyjnych stanowiła rewolucja lat 1905-1907 i zniesienie cenzury prewencyjnej w Rosji.

W oficynie Michała Arcta stosunkowo wcześnie zarysowała się podobna tendencja. Spostrzeżenie to opieram na dwóch przesłankach: po pierwsze, po 1905 roku w ramach „Książek dla Wszystkich” nie publikowano opracowań o wysokim stopniu trudności, po drugie, już w 1904 roku zainicjowano serię „Podstawy Wykształcenia Współczesnego" pomyślaną jako zbiór podręczników pomocnych w samokształceniu ${ }^{49}$. O ile omówione wcześniej samoistne publikacje redakcji „Poradnika dla Czytających Książki” stanowiły kontynuację popularnonaukowej biblioteczki przy „Poradniku dla samouków”, o tyle „Podstawy Wykształcenia Współczesnego" należy uznać za próbę nawiązania do Wykładów naukowych publikowanych w latach 1895-1899 na łamach „Przeglądu Pedagogicznego”. Wprawdzie w prospekcie nowego wydawnictwa Michała Arcta nic się nie mówi na temat źródeł inspiracji, ale zarówno koncepcja projektu, jak i proweniencja niektórych tekstów ogłoszonych w ramach nowej serii wydawniczej wskazują na bliskie związki z programem pedagogów z kręgu Jana Władysława Dawida. „Podstawy Wykształcenia Współczesnego" adresowano do osób podejmujących samodzielne studia, w doborze prac zasadę stanowiła „przewaga syntezy nad encyklopedyczną zbieraniną wiadomości”, a "cechą każdego [...] tomu [miał być] uogólniający, filozoficzny sposób ujęcia przedmiotu, bez ujmy popularności"50.

Redagowanie serii powierzono Władysławowi Mieczysławowi Kozłowskiemu, który - sam będąc autorem programu samokształcenia oraz jako uczestnik przedsięwzięcia „Przeglądu Pedagogicznego” - w oczywisty sposób korzystał z nie w pełni zrealizowanego planu sprzed kilku lat ${ }^{51}$. „Podstawy Wykształcenia Współczesnego" zainicjował Kozłowski własną pracą Klasyfikacja umiejętności ze stanowiska potrzeb wykształcenia ogólnego, w ramach serii umieścił również swój podręcznik historii filozofii - obie prace pisane przed laty dla nieukończonego cyklu redakcji „Przeglądu Pedagogicznego” 52 .

Między wydawnictwem „Przeglądu Pedagogicznego” z lat osiemdziesiątych XIX wieku a redagowaną przez Kozłowskiego serią Arctowską istniały różnice. W „Podstawach Wykształcenia Współczesnego” zrezygnowano z piśmiennictwa reprezentującego nauki przyrodnicze, ograniczając repertuar do książek z zakresu historii powszechnej i historii filozofii oraz literaturoznawstwa. Z powodu braku opracowań polskich odpowiadających założeniom serii, poza tekstami samego redaktora, wydano tylko jedną pracę autora rodzimego, mianowicie przygotowany przez Piotra Chmielowskiego na zamówienie Arcta dwutomowy Krytyczno-porównawczy przegląd dziejów piśmiennictwa polskiego (1905). Wśród kilkunastu

49 Plan serii „Podstawy Wykształcenia Współczesnego” gotowy był wcześniej. Pierwsze tomy wydawnictwa, m.in. Historia filozofii W. M. Kozłowskiego (nr 4 serii), otrzymały aprobatę cenzury jesienią 1903 r. Archiwum Główne Akt Dawnych, Warszawski Komitet Cenzury, sygn. 44, Protokoły (decyzja z 20 X 1903).

50 Cyt. za programem drukowanym na wewnętrznych stronach okładek kolejnych tomów serii.

51 B. J. Gawecki, Władysław Mieczysław Kozłowski (1858-1935), Wrocław 1961, s. 22.

52 T. Kamiński, Przegląd Pedagogiczny..., s. 56 oraz przypis 99, s. 53-54. 
pozycji opublikowanych do 1912 roku przeważały przekłady, z reguły znacznie okrojone w stosunku do oryginałów, niekiedy czytelnik otrzymywał streszczenie bądź sporządzoną przez Kozłowskiego kompilację kilku książek. Postępowanie takie było wynikiem formalnego wymogu nakładcy ograniczającego objętość przekładów do ok. dziesięciu arkuszy. Tylko prace polskie (autorstwa redaktora serii) przekraczały tę normę.

Podobne warunki ograniczające objętość tomów postawił Arct, decydując się wydawać własnym nakładem redagowaną przez Zofię Daszyńską-Golińską „Biblioteczkę Dzieł Społeczno-Ekonomicznych”. Ponieważ w założeniu wydawcy rozmiary poszczególnych tomów nie mogły przekraczać ośmiu arkuszy ${ }^{53}$, i w tym przedsięwzięciu mamy niekiedy do czynienia z poważnymi skrótami. Niemniej w krótkim czasie (1911-1914) ukazało się kilka tekstów podstawowych dla poznania dziejów polskiej myśli ekonomicznej. „Biblioteczka Dzieł Społeczno-Ekonomicznych", zamierzona pierwotnie na większą skalę, zamknęła się ostatecznie na serii pierwszej, która objęła rozprawy i traktaty dziewiętnastowiecznych ekonomistów polskich oraz studia monograficzne $z$ tego zakresu ${ }^{54}$. Rangę serii podnoszą wstępy pióra Bolesława Limanowskiego odznaczające się wysokimi walorami dydaktycznymi oraz dokonane przez Zofię Daszyńską-Golińską obszerne analizy prac i poglądów autora poprzedzające większość ogłoszonych dzieł55.

Około 1910 roku, równocześnie z omówioną wyżej „Biblioteczką Dzieł Społeczno-Ekonomicznych", programy wydawnicze pomocne w autodydaktyce na poziomie wyższym realizowały dwie oficyny warszawskie, wyraźnie różniące się czasem i zakresem działalności na rynku książki, charakterem i rozmiarami produkcji. Były to, istniejąca od ponad pięćdziesięciu lat księgarnia E. Wende i Spółka, prowadzona przez zawodowych księgarzy i wydawców, oraz nowe, powstałe na przełomie pierwszej i drugiej dekady XX wieku „inteligenckie” wydawnictwo Henryka Lindenfelda.

Księgarnia Wendego swój potencjał ekonomiczny i wysoką rangę na polskim rynku książki zdobyła dzięki prowadzonemu na wielką skalę handlowi publikacjami naukowymi. Doskonała znajomość tego segmentu rynku i próba wypełnienia luk w zakresie książki popularnonaukowej w Królestwie Polskim już wcześniej znalazła swój wyraz we współpracy firmy z wydawnictwami Iwowskimi: Nauka i Sztuka (Towarzystwa Nauczycieli Szkół Wyższych) oraz Wiedza i Życie (Związku Naukowo-Literackiego). Tę ostatnią firmowała i współfinansowała księgarnia

${ }^{53}$ Informacja pochodzi z prospektu wydawnictwa dołączonego do ogłoszonych pod numerem pierwszym Ogólnych zasad gospodarstwa narodowego Fryderyka Skarbka (1911). Por. też: W. M. Kozłowski, Biblioteka Ekonomiczno-Społeczna, „Książka” 1913, nr 11, s. 555.

${ }^{54}$ W serii „Biblioteczka Dzieł Społeczno-Ekonomicznych” wydano m.in.: Porządek fizyczno-moralny Hugona Kołłątaja, Ekonomię powszechną krajową narodów Waleriana Stroynowskiego, Szkołe polską gospodarstwa społecznego Józefa Supińskiego, Filozofię materialną ludzkiego społeczeństwa Henryka Kamieńskiego oraz pierwsze polskie przekłady Mylnych systemów ekonomicznych i Systemu ekonomiczno-społecznego Józefa Hoene-Wrońskiego. W okresie późniejszym światło dzienne ujrzały m.in. prace Fryderyka Naxa, Hieronima Stroynowskiego, Wawrzyńca Surowieckiego oraz rozprawy o poglądach Kołłątaja i Stanisława Staszica.

${ }_{55}$ Biblioteka Narodowa, rkps 2752, Korespondencja Samuela Dicksteina, k. 32-33 (list Z. Daszyńskiej-Golińskiej z 25 IV 1910). 
Alfreda Altenberga - stałego współpracownika oficyny Wendego, toteż nazwa księgarni warszawskiej jako dystrybutora na obszarze Królestwa Polskiego występowała w adresie wydawniczym książek tej serii obok nazwy nakładcy ${ }^{56}$.

Kontakty z placówkami galicyjskimi, zwłaszcza z oficyną Altenberga utrzymywał również Ludwik Fiszer, ostatni właściciel księgarni E. Wende i Sp. Powołana przez niego w 1913 roku „Biblioteka Naukowa Wendego” w jakiejś mierze stanowiła nawet kontynuację zakończonej właśnie Iwowskiej serii „Wiedza i Życie”. Jednak wobec zasadniczo odmiennych warunków życia w Królestwie i w Galicji musiały istnieć różnice w programach obu wydawnictw. O ile głównym celem serii Iwowskiej było przedstawienie wykształconym warstwom inteligencji problemów nauki współczesnej ${ }^{57}$, o tyle w „Bibliotece Naukowej Wendego” trzeba było uwzględnić potrzeby rozwijającego się ruchu samouctwa. Redaktorzy serii, Franciszek Pułaski i Ludwik Silberstein, ten aspekt nowego wydawnictwa warszawskiego wyraźnie podkreślili w prospekcie. Nie rezygnując z funkcji popularyzowania osiągnięć nauki współczesnej, do programu „Biblioteki Naukowej Wendego” włączyli dzieła prezentujące dorobek „nauki klasycznej” oraz „książki systematycznie kształcące”, które miały zapoznać czytelników „z metodami i kierunkami badań” i udzielić im „przejrzystej orientacji w rozbudowanym obszernie gmachu wiedzy”58. Podany w prospekcie plan serii obejmował zaledwie kilkanaście tytułów, wśród których przeważały przekłady podręczników i opracowań syntetyzujących zdobycze nauki ostatniego półwiecza. Redakcja, stawiając sobie za cel zarówno rozwój czytelnictwa, jak i piśmiennictwa naukowego, zapowiadała jednak powiększenie liczby nowych oryginalnych dzieł polskich. Jak wynika z informacji podawanych w przedmowach do początkowych tomów „Biblioteki Naukowej”, przewidywano jej rozszerzenie poza pierwotny projekt, który roboczo nazywano "serią pierwszą".

Wykonanie zamierzenia możliwe było tylko przy zapewnieniu sobie współpracy większego grona osób. W 1913 roku redakcja „Biblioteki Naukowej Wendego" ogłosiła listę współpracowników. Znalazły się na niej nazwiska blisko siedemdziesięciu uczonych z różnych ośrodków polskich (głównie z Warszawy, ale też z Krakowa, Lwowa i Dublan) oraz z uniwersytetów zagranicznych (Anglii, Francji, Niemiec i Włoch ${ }^{59}$. Chociaż wiele osób wyrażających gotowość udziału w przedsięwzięciu nie podjęło współpracy, a wojna przekreśliła dalszy rozwój wydawnictwa (zostało zamknięte w 1918 r. po wydaniu zapowiedzianych tytułów „serii pierwszej”), była „Biblioteka Naukowa Wendego” inicjatywą nowatorską. Przynajmniej po części spełniła nadzieje wydawcy i redaktorów, którzy chcieli w niej widzieć namiastkę uczelni wyższej. Obecność w gronie współpracowników wybitnych przedstawicieli nauki polskiej - tak humanistyki, jak i nauk matematyczno-przyrodniczych - dawała pewność trafnego wyboru tekstów obcych oraz wysokiego poziomu tłumaczeń i prac zamawianych przez redakcję; miały one

\footnotetext{
56 J. Muszkowski, E. Wende i Spółka, „Przegląd Księgarski” 1928, s. 118.

57 D. Adamczyk, Polskie społeczne placówki wydawnicze w dobie autonomii galicyjskiej, Kielce 1992, s. 74-75, 155-158; L. Zasztowt, Popularyzacja nauki..., s. 131.

58 Prospekt:. Biblioteka Naukowa Wendego, red. F. Pułaski, L. Silberstein, Warszawa b.r.w.,

59 Tamże, s. 6-7.
} s. 3-5. 
wypełnić luki w literaturze polskiej. Krytyka z uznaniem wyrażała się o kolejnych tomach, pisano, że są „wydane pod każdym względem wzorowo”60.

Uznanie krytyki zdobyły również publikacje naukowe oficyny Henryka Lindenfelda (1910-1918). Pisano o nich, że jasność wykładu łączą ze ścisłością naukową oraz że z równą korzyścią służyć mogą studentom i każdemu inteligentnemu człowiekowi. Skromny dorobek tej jednoosobowej placówki wydawniczej, obejmujący w sumie kilkanaście tytułów, tworzyły wyłącznie książki naukowe i popularnonaukowe. Lindenfeld wprawdzie nie ogłosił drukiem programu wydawniczego, ale charakter większości dzieł wpisuje je w nurt edukacyjny i samokształceniowy. Taki też wniosek można wysnuć z przedmów odautorskich określających zakładaną funkcję poszczególnych książek oraz z licznych recenzji pojawiających się w prasie po ukazaniu się kolejnych publikacji1 ${ }^{61}$.

Wydawnictwa naukowe Henryka Lindenfelda - jak informuje tytuł katalogu z 1912 roku - oprócz zbiorów studiów filozoficznych i naukoznawczych najnowszej proweniencji, obejmowały podręczniki i opracowania o charakterze syntetycznym, głównie z zakresu nauk matematyczno-przyrodniczych ${ }^{62}$. Wprawdzie Lindenfeld uprzystępnił w języku polskim kilka najnowszych opracowań poszerzających zakres oferty, m.in.: Domy dziecięce. Metoda pedagogiki naukowej stosowanej w wychowaniu najmłodszych dzieci Marii Montessori we własnym przekładzie (1913), jednak profil oficyny w dużej mierze określiło wykształcenie przyrodnicze wydawcy i udział w badaniach prowadzonych w pracowni zoologicznej Uniwersytetu Warszawskiego pod kierunkiem Józefa Nusbauma ${ }^{63}$. Swoistym rysem pracy wydawniczej Lindenfelda w ciągu kilku lat przedwojennych stało się nie tylko wprowadzanie na polski rynek książki nowych opracowań odpowiadających pojęciom nauki początku XX wieku, ale też wznowienia edycji tekstów pisanych w połowie XIX wieku w duchu pozytywistycznym. Wydawca powracał też po latach do przedsięwzięć z różnych przyczyn nieukończonych w innych oficynach warszawskich ${ }^{64}$.

W procesie kształtowania oferty publikacji upowszechniających naukę wśród inteligencji i osób zdobywających wykształcenie średnie i wyższe wydawcy profesjonalni w Królestwie Polskim dokonywali wyborów tylko do pewnego stopnia odpowiadających potrzebom odbiorców. Rynek książki popularnonaukowej,

60 Por. recenzję książki B. Russela Zagadnienia filozofii (1913), autorstwa Z. Zawirskiego, „Książka” 1914, nr 6, s. 374.

61 W katalogu księgarni pf. Ferdynanda Hoesicka (wydanym nie wcześniej niż w 1916 r., prawdopodobnie w okresie organizacji lub pierwszych lat działalności Uniwersytetu Warszawskiego) publikacje Lindenfelda umieszczono pod nagłówkiem Podręczniki uniwersyteckie.

62 Np. w 1910 r. Lindenfeld wydał (poprzedzony wstępem Krzywickiego) wybór esejów ze zbioru Darwin and modern science (Cambrigde 1909) opublikowany dla uczczenia setnej rocznicy urodzin Darwina. W doborze tekstów kierował się zamiarem ukazania wpływu teorii ewolucji na przyrodoznawstwo i filozofię. Por. K. Kulwieć, „Książka” 1911, nr 5, s. 193.

63 Por. G. Brzęk, Historia zoologii w Polsce do r. 1918, cz. 3, Lublin 1955 („Annales UMCS” 1953, Sect. C., Suppl. 7) oraz biogram H. Lindenfelda autorstwa I. Treichel w: Słownik pracowników książki polskiej. Suplement..., s. 121.

64 Np. w 1911 r. ukazał się nowy przekład (Adama Mahrburga) Psychologii w zarysie na podstawie doświadczenia Haralda Höffdinga; poprzednią edycję (w oficynie „Przeglądu Tygodniowego" Adama Wiślickiego) przerwano po śmierci tłumacza Feliksa Daszyńskiego w 1890 r. 
opracowań podsumowujących i syntetyzujących osiągnięcia wybranych dziedzin wiedzy, również $w$ formie podręczników akademickich, okazywał się zbyt mały, aby bez asekuracji środków publiczności czytającej, czerpanych z prenumeraty, podejmować poważniejsze przedsięwzięcia i kontynuować je z powodzeniem w dłuższym czasie. Dodatkowe przeszkody stwarzała cenzura ograniczająca repertuar. Duże oficyny, Michała Arcta, Gebethnera i Wolffa, Teodora Paprockiego i Spółki, niewątpliwie osiągnęły poważniejsze efekty w tej dziedzinie.

W procesie kształtowania oferty książek niebeletrystycznych wydawcy profesjonalni nie odwracali się od książki upowszechniającej naukę. Ich uczestnictwo w tym segmencie produkcji wydawniczej zmieniało się wraz z rozwojem rynku i sukcesywnie postępującą specjalizacją oficyn. Pewien wpływ na zmiany obserwowane pod koniec XIX i na początku XX wieku miał proces wyodrębnienia się i ukształtowania wąskospecjalistycznego pisarstwa stricte naukowego. Na to pole wydawcy komercyjni wstępowali wyjątkowo, skłaniając się raczej ku finansowaniu nakładów opracowań dostępnych dla szerszych kręgów inteligencji i kształcącej się młodzieży. 